University of Nebraska - Lincoln

DigitalCommons@University of Nebraska - Lincoln

Faculty Publications: Department of

Entomology

Entomology, Department of

2013

\title{
Non Target Effect of Cry1 Ab and Cry Ab x Cry3 Bb1 Bt Transgenic Maize on Orius insidiosus (Hemiptera: Anthocoridae) Abundance
}

\author{
Santiago A. Palizada \\ University of Nebraska-Lincoln \\ Difabachew K. Belay \\ University of Nebraska-Lincoln, difabachewbelay@yahoo.com \\ Bamphitlhi Tiroesele \\ University of Nebraska-Lincoln \\ Fatima Mustafa \\ University of Nebraska-Lincoln \\ Muhammad Ullah \\ University of Nebraska-Lincoln, mirfanullah@uos.edu.pk
}

See next page for additional authors

Follow this and additional works at: https://digitalcommons.unl.edu/entomologyfacpub

Part of the Entomology Commons

Palizada, Santiago A.; Belay, Difabachew K.; Tiroesele, Bamphitlhi; Mustafa, Fatima; Ullah, Muhammad; Hunt, Thomas; Molina-Ochoa, Jaime; Skoda, S. R.; Clark, Pete L.; and Foster, John E., "Non Target Effect of Cry1 Ab and Cry Ab x Cry3 Bb1 Bt Transgenic Maize on Orius insidiosus (Hemiptera: Anthocoridae) Abundance" (2013). Faculty Publications: Department of Entomology. 548.

https://digitalcommons.unl.edu/entomologyfacpub/548

This Article is brought to you for free and open access by the Entomology, Department of at DigitalCommons@University of Nebraska - Lincoln. It has been accepted for inclusion in Faculty Publications: Department of Entomology by an authorized administrator of DigitalCommons@University of Nebraska - Lincoln. 


\section{Authors}

Santiago A. Palizada, Difabachew K. Belay, Bamphitlhi Tiroesele, Fatima Mustafa, Muhammad Ullah, Thomas Hunt, Jaime Molina-Ochoa, S. R. Skoda, Pete L. Clark, and John E. Foster 


\title{
Non Target Effect of Cry1 Ab and Cry Ab x Cry3 Bb1 Bt Transgenic Maize on Orius insidiosus (Hemiptera: Anthocoridae) Abundance
}

Santiago A. Palizada ${ }^{1,5}$, Difabachew K. Belay ${ }^{1,2}$, Bamphitlhi Tiroesele ${ }^{1}$, Fatima Mustafa ${ }^{1}$, Muhammad Irfan Ullah¹, Thomas Hunt ${ }^{3}$, Jaime Molina-Ochoa ${ }^{1,6^{*}}$, Steven R. Skoda ${ }^{7}$, Pete L. Clark ${ }^{4}$ and John E. Foster ${ }^{1}$

${ }^{1}$ Department of Entomology, Insect Genetics Laboratory, University of Nebraska-Lincoln, 103 Entomology Hall, Lincoln, NE 68583-0816, USA

${ }^{2}$ Dow Agro Sciences, 18078 N 1500 E Road, Pontiac, IL 61764, USA

${ }^{3}$ University of Nebraska, Haskell Agricultural Laboratory, 57905866 Road, Concord, NE. 68728, USA

${ }^{4}$ Simplot -Manager Regulatory Affairs, 5369 W. Irving Street, Boise, Idaho 83706, USA

${ }^{5}$ Department of Agriculture-Bureau of P lant Industry, 692 San Andres S t., Malate, Manila

1004, Philippines

${ }^{6}$ Universidad de Colima, Coordinación General de Investigación Científica, Centro Universitario de Investigación y Desarrollo Agropecuario, Km 40 autopista ColimaManzanillo, Tecomán, Colima 28930, México

7USDA-ARS-KBUSLIRL Screwworm Research Unit, Kerrville, TX 78028, USA

\begin{abstract}
Non-target effects of Cry $1 \mathrm{Ab} \times \mathrm{CP} 4$ EPSPS and Cry $1 \mathrm{Ab}+\mathrm{Cry3Bb} 1 \times \mathrm{CP} 4$ EPSPS Bt transgenic new maize hybrids on insidious flower bugs [Orius insidiosus (Say)] was studied in Nebraska (Mead, Clay Center, and Concord) during 2007 and 2008. The Bt effect was compared to CP4 EPSPS maize (isoline), conventional maize, and insecticide applications of permethrin (Pounce ${ }^{\circledR} 1.5 \mathrm{G}$ ) and bifenthrin (Capture ${ }^{\circledR} 2 \mathrm{EC}$ ) to control first and second generations of Ostrinia nubilalis (Hübner), respectively. Yellow sticky cards, visual observations, and destructive samplings were used to evaluate $O$. insidio sus abundance. The yellow sticky card data in 2007 showed that $O$. in sidiosus abundance was lower on Pounce ${ }^{\mathbb{E}}$ 1.5G treated non-Bt isoline maize plots compared to the $\mathrm{BT}$ transgenic hybrids at 60 and 90 days after planting (DAP). From visual observations, numbers of $O$. insidiosus were lower in Pounce ${ }^{\circledR} 1.5 \mathrm{G}$ treated plots and no adverse effects of the Bt hybrids was observed. In 2008, no significant differences were found among treatments in the sticky card data, but the $O$. insidiosus population significantly increased, with increasing DAP, where the lowest and highest numbers were recorded at 30 and $120 \mathrm{DAP}$, respectively. In the visual observation and destructive samplings, numbers of $O$. insidiosus were lower at Concord compared to other sites. Results from the visual observation data in 2008 also revealed that $O$. insidiosus abundance was lower on Pounce ${ }^{\circledR} 1.5 \mathrm{G}$ treated plots compared to other treatments. This study showed no adverse effects of the new BT transgenic hybrids that included stacked resistance genes on $O$. insidiosus compared to the non-Bt maize hybrids.
\end{abstract}

Keywords: Orius insidiosus; Non-target effects; BT transgenic maize

\section{Introduction}

Insect resistance based on Bacillus thuringiensis (Bt) (Berliner) endotoxins is the most widely used trait following herbicide tolerance in commercial transgenic crops [1]. The deployment of transgenic plants resistant to insects offered expectations as a means of pest control that led to a reduction in pesticide use in intensive cropping systems.

Although the increased global adoption of transgenic crops [2] shows usefulness for many growers and their acceptance in many markets, the imposition of moratoria in several countries reflects skepticism and public concern about a range of issues around transgenics including potential impacts on the environment. Potential adverse effects of transgenics on the environment include effects on nontarget species, invasiveness, release or "escape" into the environment, and development of resistance to transgenic products [3]. To address these concerns, governments have authorized regulatory bodies like the U.S. Environmental Protection Agency to regulate the deployment of transgenics requiring environmental risk assessment data as part of the registration process [4].

Orius insidiosus (insidiosus flower bugs) (Hemiptera: Anthocoridae) are generalist predators which are frequently reported in ecological studies as important non-target organisms in transgenic maize [5-8]. In the Midwest, including Nebraska, $O$. insidiosus is a common predator in maize (Wright 2004) and soybean fields [9].

Orius spp. are important natural enemies of pest insects and mites in many cropping systems such as maize, soybeans, vegetables, and fruit crops [10,11]. Nearly all Orius spp. are predaceous as nymphs and adults. The primary food of Orius spp. consists of small insects and insect eggs, plant pollen, and plant sap [12]. Nymphs and adults of $O$. insidiosus are commonly found on maize silks and serve as natural enemies of key maize pests such as of Ostrinia nubilalis (Hübner), Helicoverpa zea (Hübner) [13], Spodoptera frugiperda (J.E. Smith) [14], Rhopalosiphum maidis (F itch) $[9,15,16]$, Frankliniella spp. [12,17,18], spider mites, white flies (Bemisia spp.), and eggs of other insects in the field. $O$. insidiosus are commercially mass produced and sold as biocontrol agents against pests of glasshouse- grown vegetables and ornamental crops [19].

The potential non-target impact of transgenic maize was studied using $O$. insidiosus as a key non-target arthropod $[5,8,20]$. Effective and reliable sampling of $O$. insidiosus nymphs and adults is important

*Corresponding author: Jaime Molina-Ochoa, Universidad de Colima Coordinación General de Investigación Científica, Centro Universitario de Investigación y Desarrollo Agropecuario, Km. 40 autopista ColimaManzanillo, Tecomán, Colima 28930, México, Tel: 52 (313) 3229413; E-mail: jmolina18@hotmail.com

Received January 05, 2013; Accepted June 28, 2013; Published July 01, 2013

Citation: Palizada SA, Belay DK, Tiroesele B, Mustafa F, Ullah MI, et al. (2013) Non Target Effect of Cry1 Ab and Cry Ab x Cry3 Bb1 Bt Transgenic Maize on Orius insidiosus (Hemiptera: Anthocoridae) Abundance. Entomol Ornithol Herpetol 2: 107. doi:10.4172/2161-0983.1000107

Copyright: (c) 2013 Palizada SA, et al. This is an open-access article distributed under the terms of the Creative Commons Attribution License, which permits unrestricted use, distribution, and reproduction in any medium, provided the original author and source are credited. 
in assessing the impact of transgenic corn on non-target organisms, particularly for environmental risk assessments. Previous ecological studies have assessed the non-target effects of transgenic maize by using visual observations, pitfall traps, sticky cards, sweep nets, and beat buckets $[7,8,21,22]$.

Non-destructive (visual observations), yellow sticky card $s$, and destructive sampling techniques have been used to monitor $O$. insidiosus nymphs and adults together with above ground arthropods pests for the non-target impact of transgenic plants $[5,6,8,22,23]$. These techniques were used to approach the objective of this study, to evaluate the non-target effects of different Bt transgenic maize hybrids on $O$. insidiosus abundance compared to insecticide applications and nontransgenic maize.

\section{Materials and Methods}

\section{Experimental sites and description}

The experiments were conducted during 2007 and 2008 at three geographically different experimental research stations of University of Nebraska-Lincoln. The experimental fields were located at the Agricultural Research and Development Center, Mead, (N41 ${ }^{\circ} 1.07^{\prime}$ WO96 $6^{\circ} 27.263^{\prime}$ in 2007 and N41 ${ }^{\circ} 11.09^{\prime}$ WO96 $6^{\circ} 27.411^{\prime}$ in 2008), South Central Agricultural Laboratory, Clay Center, (N40 '34.216’ WO98 ${ }^{\circ} 07.958^{\prime}$ in 2007 and $\mathrm{N}^{\circ} 0^{\circ} 34.272^{\prime}$ WO98 ${ }^{\circ} 07.822^{\prime}$ in 2008 ), and the Northeast Research and Extension Center, Haskell Agricultural Laboratory, Concord, (N42 $23.037^{\prime}$ WO96 $^{\circ} 57.193^{\prime}$ in 2007 and $\mathrm{N}^{\circ} 2^{\circ} 23.149^{\prime} \mathrm{WO}^{\circ} 6^{\circ} 5.331^{\prime}$ in 2008) . Soil types were Sharpsburg silty clay loam, Kennebec silty clay loam, and Butler/Crete silt loam, respectively. The experimental fields at all locations were previously planted with soybeans in a no tillage system.

\section{Agronomic practices}

Plantings were done in a no-till corn system on 10,11 and 15 May in 2007, and during 19, 20 and 21 May in 2008 at Mead, Clay Center, and Concord, respectively. Fertilizer management, irrigation, and herbicide application were made based on the normal agronomic recommendations of each specific site.

\section{Experimental design and treatments}

A randomized complete block design with four replications was used. The treatments were: a) a Cry1 Ab X CP4 EPSPS maize, b) CP4 EPSPS maize (isoline), c) CP4 EPSPS maize (isoline) plus an insecticide application to control the first generation of $O$. nubilalis, $\mathrm{d}$ ) Cry1 Ab+Cry3Bb1X CP4 EPSPS maize, e) CP4 EPSPS maize (isoline) plus an insecticide application to control second generation of $O$. nubilalis, and f) a conventional maize without insecticide application. The Cryl Ab Bt transgenic maize is used to control lepidopteran pests while Cry3Bblis used against corn root worms (Diabrotica spp.). The CP4 EPSPS is a genetically engineered glyphosate tolerant maize variety which allows the use of glyphosate as a postemergence herbicide.

In the case of CP4 EPSPS maize plus an insecticide application to control the first generation of O. nubilalis both in 2007 and 2008, permethrin (Pounce ${ }^{\circledR} 1.5 \mathrm{G}$ ) (FMC Corporation, PA) was applied at the recommended rate of $12 \mathrm{oz}$. $/ 1000$ row $\mathrm{ft}$ band using an improvised jar shaker applicator at whorl maize stage (V9-V12 growth stages). Bifenthrin (Capture ${ }^{\circledR} 2$ EC) (Bayer, NJ) was sprayed at the rate of 6.66 $\mathrm{ml} / 2$ gallons of water using a carbon-gated sprayer for the control of second generation $O$. nubilalis. Individual plots were 60 square meters. There were 8 rows in each plot with $\sim 400$ plants per plot $(\sim 50$ plants per row). A $3 \mathrm{~m}$ spacing between treatments and blocks was planted with conventional corn hybrid.

\section{Sampling methods}

O. insidiosus nymphs and adults were monitored using visual observations, and adults with yellow sticky cards, in 2007 and 2008 . A destructive sampling technique was added in 2008 to validate the actual nymph and adult counts. Visual observations were made on 20 randomly selected plants from rows 2 and 3 in each plot at reproductive stages, R1 (silking) and R2 (blister) i.e. 80 and 90 DAP, respectively. Nymphs and adults of $O$. insidiosus were observed on maize ears, and silks were tapped and $O$. insidiosus falling from the silk were collected with a clean sheet of bond paper underneath to quantify the number of nymphs and adults. The mean nymph plus adult counts per plant were used for the analysis.

Two yellow sticky cards $(23 \times 28 \mathrm{~cm})$ per plot (sticky on one side only) (Pherocon ${ }^{\circledR}$ AM, Trécé Inc., Adair, OK) $[7,8]$ were used. The traps were attached to wooden stakes $(2.5 \times 2.1 \times 244 \mathrm{~cm})$ that were placed between rows 5 and 6, 6 and 7 of each plot at the seedling stage (V3). The yellow stick cards were attached on the wooden stakes at 30 , 60,90 , and 120 DAP. The cards were folded and clipped with 2 binder clips around the wooden stake facing the maize rows at the canopy level during the vegetative stage and parallel to the ears in the reproductive stages. After 7 days, the yellow sticky cards were collected, sealed in ziplock plastic bags, and brought to the laboratory for quantification. $O$. insidiosus adults were counted with the aid of a dissecting microscope. The adult counts from the 2 yellow sticky cards were pooled, and mean adult counts per card per day were used for the analysis.

Destructive sampling was done on five randomly selected maize ears from row 4 of each plot at R2. The randomly sampled maize ears were cut from the plant using a knife and kept in a ziplock plastic bag separately and brought to the laboratory for counting. Adults and nymphs of $O$. insidiosus were counted using a dissecting microscope. Mean number of nymphs and adults of the five ears per plot were pooled for the analysis. Voucher specimens of $O$. insidiosus were kept at University of Nebraska-Lincoln, Department of Entomology.

\section{Data analysis}

Analysis of variance (ANOVA) was performed using SAS's PROC GLM procedure (SAS, 2003) [24]. The level of significance was set at $\mathrm{P}=0.05$. Whenever there was significant interaction among factors (treatment, sampling period, location, season), each factor was analyzed with respect to the levels of the other factor. In the absence of significant interaction, data were pooled. The treatment $\mathrm{x}$ site effects generally revealed no significant differences, and these were not presented in the results and discussion. For parameters that showed significant difference among treatments, individual means were separated using the Student's Newman Keuls test (SNK).

\section{Results}

There was a significant interaction in 2007 between treatments and sampling period for the yellow sticky card data $(F=2.29, P=0.0050$, $d f=15,216$ ), so treatments were compared at a specific sampling period. Abundance of $O$. insidiosus also significantly varied among locations $(F=16.72, P<0.0001, d f=2,216)$. Significant differences among treatments were observed at $60 \mathrm{DAP}(F=3.48, P=0.0076, d f=5,64)$ and 90 DAP $(F=4.26, P=0.0117, d f=5,64)$; numbers of $O$. insidiosus were significantly lower on Pounce ${ }^{\circledR}$ 1.5G treated CP4 EPSPS maize (isoline) compared to the rest of the treatments including the transgenic hybrids 
Citation: Palizada SA, Belay DK, Tiroesele B, Mustafa F, Ullah MI, et al. (2013) Non Target Effect of Cry1 Ab and Cry Ab x Cry3 Bb1 Bt Transgenic Maize on Orius insidiosus (Hemiptera: Anthocoridae) Abundance. Entomol Ornithol Herpetol 2: 107. doi:10.4172/2161-0983.1000107

Page 3 of 5

\begin{tabular}{|c|c|c|c|c|}
\hline \multirow[t]{2}{*}{ Treatment } & \multicolumn{4}{|c|}{ Sampling periods (days after planting) } \\
\hline & 30 days & 60 days & 90 days & 120 days \\
\hline Cry1Ab & $0.05 \pm 0.02$ & $0.88 \pm 0.15 a$ & $0.81 \pm 0.11 a$ & $1.14 \pm 0.09$ \\
\hline CP4 EPSPS maize & $0.018 \pm 0.01$ & $0.77 \pm 0.15 \mathrm{ab}$ & $0.84 \pm 0.12 a$ & $1.06 \pm 0.16$ \\
\hline Pounce $^{\circledR}$ 1.5G & $0.05 \pm 0.02$ & $0.46 \pm 0.09 \mathrm{~b}$ & $0.45 \pm 0.07 \mathrm{~b}$ & $1.57 \pm 0.18$ \\
\hline Cry1Ab x Cry3Bb1 & $0.018 \pm 0.01$ & $0.75 \pm 0.13 a b$ & $0.77 \pm 0.09 a$ & $1.28 \pm 0.27$ \\
\hline Capture $^{\circledR} 2$ EC & $0.036 \pm 0.01$ & $0.93 \pm 0.19 a$ & $0.82 \pm 0.12 a$ & $1.17 \pm 0.18$ \\
\hline Conventional corn & $0.01 \pm 0.01$ & $0.65 \pm 0.12 \mathrm{ab}$ & $0.85 \pm 0.08 a$ & $1.19 \pm 0.16$ \\
\hline
\end{tabular}

Means within a column followed by the same letter are not statistically different from each other $(\mathrm{SNK}, \mathrm{P}=0.05)$. Ns $=$ not significant. Pounce ${ }^{\circledR} 1.5 \mathrm{G}$ and Capture 2 EC was applied on CP4 EPSPS maize

Table 1: Mean number of $O$. insidiosus ( $\pm \mathrm{S} E$ ) in $\mathrm{BT}$ transgenic maize hybrids and non transgenic insecticide treated and non-treated hybrids during the 2007 cropping season.

\begin{tabular}{|c|c|c|c|c|c|}
\hline \multirow[b]{3}{*}{$\begin{array}{c}\text { Experimental } \\
\text { Site }\end{array}$} & \multicolumn{5}{|c|}{ Season } \\
\hline & \multicolumn{2}{|c|}{2007} & \multicolumn{3}{|c|}{2008} \\
\hline & Sticky card & $\begin{array}{c}\text { Visual } \\
\text { observation }\end{array}$ & Sticky card & $\begin{array}{c}\text { Visual } \\
\text { observation }\end{array}$ & $\begin{array}{l}\text { Destructive } \\
\text { sampling }\end{array}$ \\
\hline Clay Center & $0.84 \pm 0.07 a$ & $0.25 \pm 0.03 c$ & $0.66 \pm 0.08 b$ & $1.74 \pm 0.73 a$ & $2.93 \pm 0.20 a$ \\
\hline Concord & $0.70 \pm 0.05 b$ & $0.77 \pm 0.05 a$ & $0.83 \pm 0.13 a$ & $0.37 \pm 0.03 b$ & $0.66 \pm 0.11 c$ \\
\hline Mead & $0.53 \pm 0.05 c$ & $0.58 \pm 0.04 b$ & $0.54 \pm 0.06 b$ & $1.63 \pm 0.16 a$ & $1.81 \pm 0.13 b$ \\
\hline
\end{tabular}

Means within a column followed by the different letter are significantly different from each other (SNK, $\mathrm{P}=0.05)$

Table 2: Mean number of $O$. insidiosus ( $\pm S E$ ) in BT transgenic maize hybrids and non transgenic insecticide treated and non-treated hybrid $\mathrm{s}$ at $\mathrm{C}$ lay Center, Concord, and Mead in Nebraska during the 2007 and 2008 cropping seasons.

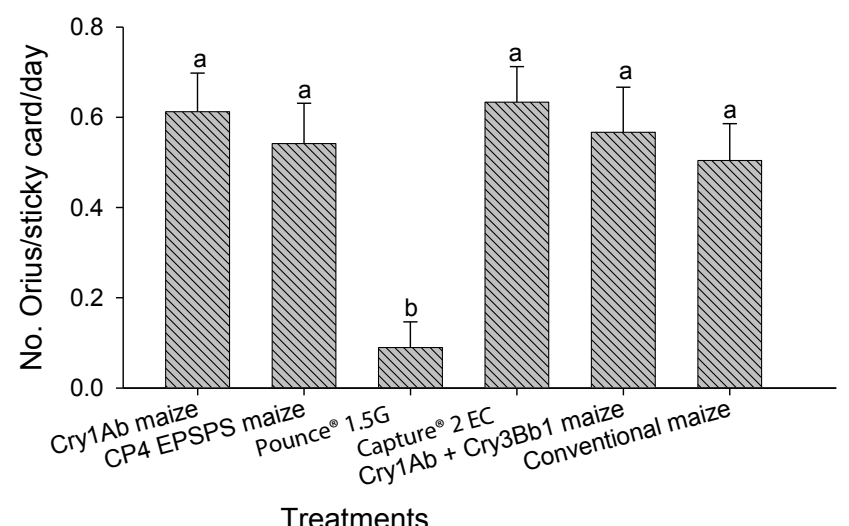

Figure 1: Mean number of $O$. insidiosus $( \pm S E$ ) in BT transgenic maize hybrids and non-transgenic insecticide treated and non-treated hybrids using a visual observation sampling technique during the 2007 cropping season in Nebraska. Bars followed by different letter are significantly different from each other (SNK $\mathrm{P}=0.05)$. Pounce ${ }^{\circledR} 1.5 \mathrm{G}$ and Capture ${ }^{\circledR} 2 \mathrm{EC}$ was applied on CP4 EPSPS maize.

Cry1 Ab, and Cry1 Ab+Cry3Bb1. Similarly at $90 \mathrm{DAP}$, lower O. insidiosus numbers were recorded from Pounce ${ }^{\circledR} 1.5 \mathrm{G}$ treated plots compared to other treatments; there were no significant differences in abundance of O. insidiosus among the rest of the treatments (Table 1). Although there were significant differences among locations, and sampling techniques in terms of $O$. insidiosus abundance, the results were not consistent in the different sampling techniques. In the season 2007, the sticky card sampling recorded higher numbers of $O$. insidiosus from Clay Center, followed by Concord, and Mead, respectively (Table 2). However, in the visual observation sampling technique, we found higher numbers of $O$. insidiosus at Concord followed by Mead and Clay Center, respectively (Table 2). The visual observation data in 2007 also showed significant differences among treatments $(F=54.4, P<0.0001, d f=5,54)$. Similar to the sticky card data, $O$. insidiosus populations were significantly lower on Pounce ${ }^{\circledR} 1.5 \mathrm{G}$ treated plots than the rest of the treatments (Figure 1). Moreover, data not shown adverse effect of the Bt transgenic hybrids compared to the isoline and conventional counterparts (Figure 1).

During the 2008 cropping season, the sticky card data showed no significant differences among treatments $(F=2.13, P=0.0624$, $\mathrm{df}=5,274)$. However, there was significant differences among sampling periods $(F=255.56, P<0.0001, d f=3,216)$ and locations $(F=9.17, P=0.0001, d f=2,216)$. $O$. insidiosus abundance significantly increased with DAP and the highest (1.95 O. insidiosus per sticky card per day) was recorded at $120 \mathrm{DAP}$ and no O. insidiosus recorded at 30 DAP (Figure 2). When we compared the experimental sites sampled by sticky card, $O$. insidiosus populations were higher at Concord and there was no significant difference between Clay Center and Mead (Table 2). However, in the visual observation and destructive sampling techniques, lower numbers of $O$. insidiosus were recorded from Concord compared to the other sites.

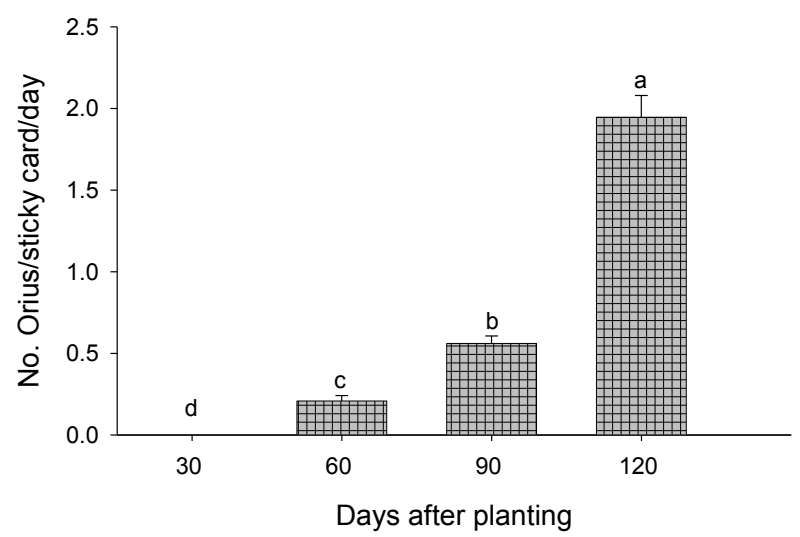

Figure 2: Mean number of $O$. insidiosus ( $\pm \mathrm{SE}$ ) in $\mathrm{BT}$ transgenic maize hybrids and non-transgenic insecticide treated and non-treated hybrids at different sampling periods using a yellow sticky card trapping method during the 2008 cropping season in Nebraska. Bars followed by different letter are significantly different from each other (SNK, $\mathrm{P}=0.05)$.

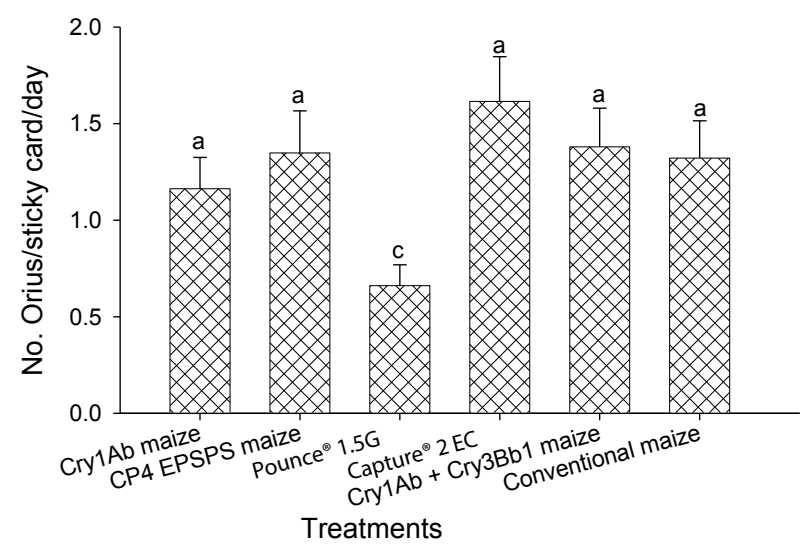

Figure 3: Abundance of $O$. insidiosus (mean $\pm \mathrm{SE}$ ) in $\mathrm{BT}$ transgenic maize hybrids and non-transgenic insecticide treated and non-treated hybrids during the 2008 cropping season in Nebraska using a visual observation sampling technique. Bars followed by the same letter are not statistically different from each other (SNK, $\mathrm{P}=0.05$ ). Pounce ${ }^{\circledR} 1.5 \mathrm{G}$ and Capture ${ }^{\circledR} 2 \mathrm{EC}$ was applied on CP4 EPSPS maize. 
Citation: Palizada SA, Belay DK, Tiroesele B, Mustafa F, Ullah MI, et al. (2013) Non Target Effect of Cry1 Ab and Cry Ab x Cry3 Bb1 Bt Transgenic Maize on Orius insidiosus (Hemiptera: Anthocoridae) Abundance. Entomol Ornithol Herpetol 2: 107. doi:10.4172/2161-0983.1000107

Page 4 of 5

In the visual observations in 2008 , there was a significant threeway interaction among sampling periods, locations (sites), and treatments $(F=18.23, P<0.0001, d f=12,108)$. Therefore, treatments were compared for each location separately at a specific sampling period. At Clay Center, significantly lower numbers of O. insidiosus were recorded from Pounce ${ }^{\circledR}$ 1.5G treated transgenic isoline maize hybrid (glyphosate resistant) both at 80 and 90 DAP compared to the other treatments (Table 3). Similarly, at Concord, abundance of O. insidiosus was significantly higher in Cry1 Ab and CrylAb X Cry1Bb hybrid compared to the non-transgenic isoline treated with Pounce ${ }^{\circledR}$ 1.5G to control first generation of O. nubilalis. Moreover, at 90 DAP; a higher number of $O$. insidiosus was recorded from Capture ${ }^{\circledR} 2$ EC treated plots compared to Pounce ${ }^{\circledR} 1.5 \mathrm{G}$ treated plots (Table 3). At Mead, $O$. insidiosus abundance was also significantly lower in Pounce ${ }^{\circledR}$ 1.5G treated plots than the other treatments at $80 \mathrm{DAP}$, and there were no significant differences among treatments at $90 \mathrm{DAP}(F=0.87, P=0.5263$, $\mathrm{df}=5,15)$. The overall treatment effect in the visual observations of 2008 season indicated that significantly lower numbers of $O$. insidiosus were recorded from Pounce ${ }^{\circledR} 1.5 \mathrm{G}$ treated isoline than other treatments including the Bt transgenic hybrids (Figure 3). Moreover, O. insidiosus abundance showed a similar trend in the destructive sampling where Orius counts were significantly lower in Pounce ${ }^{\circledR}$ 1.5G treated plots than the Bt transgenic hybrids, the non-transgenic isoline, conventional maize, and Capture ${ }^{\circledR} 2$ EC sprayed conventional maize (Figure 4).

\section{Discussion}

Visual observations, yellow sticky cards and destructive sampling techniques revealed the same trend of significantly fewer mean adult counts of $O$. insidiosus on CP4 EPSPS maize plus Pounce ${ }^{\circledR} \quad 1.5 \mathrm{G}$ for the control of first generation O. nubilalis at R2 (blister) stage. Neither Bt transgenic maize hybrids had observable effects on populations of $O$. insidiosus in all sampling techniques used in the study. O. insidiosus nymphs and adults were fewer on insecticide treated CP4 EPSPS maize. These findings support previous ecological studies on non-target predators that transgenic maize does not have a significant negative effect on the predator $O$. insidiosus, but our results differ with those previously reported because we obtained significant differences in the sampling techniques $[7,8,20,22,25,26]$.

The results of our study suggested that visual observation, yellow sticky cards, and destructive sampling are effective in monitoring abundance of $O$. insidiosus in non-target studies. These results corroborate other ecological field studies on non-target arthropods of transgenic maize. Al-deeb et al. [5] used visual counts of $O$. insidiosus in $B t$ and non- $B t$ maize fields at three locations in Kansas to show that $B t$ maize does not have significant effects on O. insidiosus. Musser et al. [7] also recommended the use of field counts of immature and adults, because these counts are accurate, have no associated supply costs, and can be made quickly. In a similar study using yellow sticky cards, Pilcher et al. [8] showed that significantly higher numbers of adult $O$. insidiosus preferred the early planting date of $B t$ hybrids during the first $O$. nubilalis generation. The variation in O. insidiosus population abundance among the three sites may be due to slight variation in biotic and abiotic factors [22]. Moreover, development of O. insidiosus is very dependent on temperature [12], and availability of food supply [19,27].

In conclusion, our findings support non-target arthropod ecological

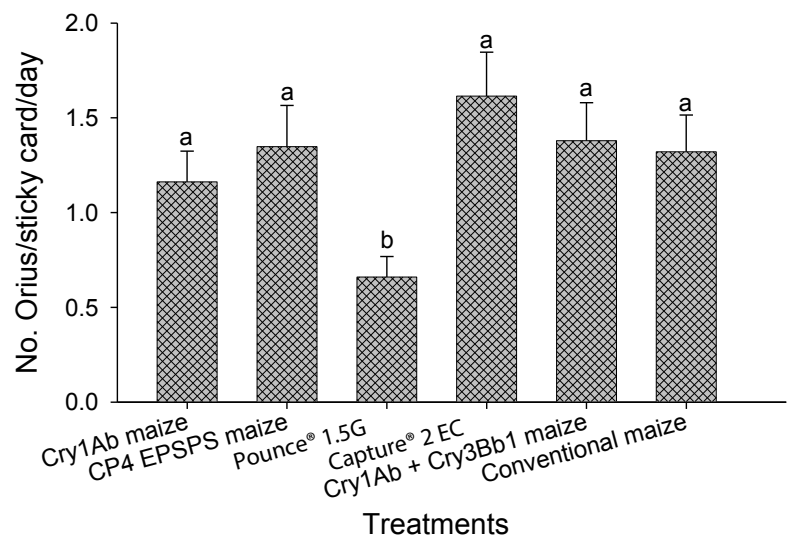

Figure 4: Abundance of $O$. insidiosus (mean $\pm \mathrm{SE}$ ) in BT transgenic maize hybrids and non-transgenic insecticide treated and non-treated hybrids during the 2008 cropping season in Nebraska using a destructive sampling technique. Bars followed by the same letter are not statistically different from each other (SNK, $P=0.05)$ Pounce $^{\circledR} 1.5 \mathrm{G}$ and Capture ${ }^{\circledR} 2$ EC was applied on CP4 EPSPS maize.

\begin{tabular}{|c|c|c|c|c|c|c|}
\hline \multirow{2}{*}{ Treatments } & \multicolumn{2}{|c|}{ Clay Center } & \multicolumn{2}{|c|}{ Concord } & \multicolumn{2}{|c|}{ Mead } \\
\hline & 80 days & 90 days & 80 days & 90 days & 80 days & 90 days \\
\hline Cry1Ab & $2.08 \pm 0.19 a$ & $1.09 \pm 0.16 b$ & $0.34 \pm 0.03 a$ & $0.53 \pm 0.13 a b$ & $2.18 \pm 0.27 a$ & $0.78 \pm 0.13$ \\
\hline CP4 EPSPS Maize & $2.00 \pm 0.31 a$ & $1.88 \pm 0.04 a$ & $0.19 \pm 0.05 a b$ & $0.44 \pm 0.14 a b$ & $2.85 \pm 0.44 a$ & $0.75 \pm 0.19$ \\
\hline Pounce $^{\circledR} \quad 1.5 \mathrm{G}$ & $0.85 \pm 0.22 b$ & $1.00 \pm 0.12 b$ & $0.09 \pm 0.024 b$ & $0.23 \pm 0.06 b$ & $1.29 \pm 0.27 c$ & $0.51 \pm 0.19$ \\
\hline Capture $^{\circledR} 2 \mathrm{EC}$ & $2.54 \pm 0.36 a$ & $1.88 \pm 0.08 a$ & $0.30 \pm 0.07 a b$ & $0.74 \pm 0.11 a$ & $3.33 \pm 0.09 a$ & $0.91 \pm 0.17$ \\
\hline Cry1Ab x Cry3Bb1 & $2.30 \pm 0.15 a$ & $1.71 \pm 0.04 a$ & $0.34 \pm 0.07 a$ & $0.49 \pm 0.12 a b$ & $2.70 \pm 0.38 a$ & $0.74 \pm 0.04$ \\
\hline Conventional Maize & $1.94 \pm 0.17 a$ & $1.63 \pm 0.19 a$ & $0.29 \pm 0.08 a b$ & $0.51 \pm 0.04 a b$ & $2.84 \pm 0.19 a$ & $0.73 \pm 0.07$ \\
\hline
\end{tabular}

Means within a column followed by the same letter are not statistically different from each other $(\mathrm{SNK}, \mathrm{P}=0.05)$. Ns $=$ not significant. Pounce ${ }^{\circledR} \quad 1.5 \mathrm{G}$ and $\mathrm{Capture}(\mathbb{R} 2 \mathrm{EC}$ was applied on CP4 EPSPS maize.

Table 3: Abundance of $O$. insidiosus (mean $\pm S E$ ) in BT transgenic maize hybrids and non transgenic insecticide treated and non-treated hybrid s at $C$ lay Center, Concord, and Mead in Nebraska during the 2008 cropping season using a visual observation sampling technique. 
Citation: Palizada SA, Belay DK, Tiroesele B, Mustafa F, Ullah MI, et al. (2013) Non Target Effect of Cry1 Ab and Cry Ab x Cry3 Bb1 Bt Transgenic Maize on Orius insidiosus (Hemiptera: Anthocoridae) Abundance. Entomol Ornithol Herpetol 2: 107. doi:10.4172/2161-0983.1000107

Page 5 of 5

field studies that Cry1 Ab, and Cry1 Ab+Cry3Bb1 maize have no impact on $O$. insidiosus populations. However, the pyrethroid insecticide (Pounce $^{\circledR} 1.5 \mathrm{G}$ ) applications to control target pests significantly affected non-target natural enemies of the target pests.

\section{Acknowledgements}

We would like to thank Bill McCormick, Terry DeVries, Gerald Echtenkamp Karl Brauer, Rosana Serikawa, Erica Lindroth, Khanoporn Tangtrakulwanich, and summer student technicians for assistance during the corn growing seasons. We also thank the Fulbright-Philippine Agriculture Scholarship Program, Department of Agriculture-Bureau of Plant Industry, Monsanto Company, and the University of Nebraska-Lincoln for their financial assistance.

\section{References}

1. O'Callaghan M, Glare TR, Burgess EP, Malone LA (2005) Effects of plants genetically modified for insect resistance on nontarget organisms. Annu Rev Entomol 50: 271-292.

2. James C (2008) Global status of commercialized biotech/GM crops: 2007 Ithaca, NY:ISAAA. Retrieve at http://www.org/main.htm. Accessed on June 08 2008

3. Conner AJ, Glare TR, Nap JP (2003) The release of genetically modified crops into the environment. Part II. Overview of ecological risk assessment. Plant $J$ 33: $19-46$

4. Naranjo S, Head G, Dively GP (2005) Field studies assessing arthropod nontarget effects in Bt transgenic crops: Introduction. Environmental Entomology 34: $1178-1180$

5. Al-deeb AM, Wilde GE, Higgins R (2001) No effect of Bacillus thuringiensis corn and Bacillus thuringiensis on predator Orius insidiosus (Hemiptera: Anthocoridae). Environmental Entomology 30: 625-629.

6. Jasinski JR, Eisley JB, Young CE, Kovach J, Willson H (2003) Select non-target arthropod abundance in transgenic and non-transgenic field crops of Ohio. Environmental Entomology 32: 407-413.

7. Musser FR, Nyrop JP, Shelton AM (2004) Survey of predators and sampling method comparison in sweet corn. J Econ Entomol 97: 136-144.

8. Pilcher CD, Rice ME, Obrycki JJ (2005) Impact of transgenic Bacillus thuringiensis corn and crop phenology on five non-target arthropods. Environmental Entomology 34: 1302-1316.

9. Brosius TR, Higley LG, Hunt TE (2007) Population dynamics of soybean aphid and biotic mortality at the edge of its range. J Econ Entomol 100: 1268-1275.

10. Jarvis JL, Guthrie WD (1987) Ecological studies of the European corn borer (Lepidoptera: Pyralidae) in Boone County, lowa. Environmental Entomology 16: $50-58$

11. Bush L, KringTJ, Ruberson JR (1993) Suitability of greenbugs, cotton aphids and Heliothis virescens eggs for development and reproduction of Orius insidiosus. Entomol. Exp. Appl. 67: 217-222.

12. Riudavets $\mathrm{J}$ (1995) Predators of Frankliniella occidentalis (Perg.) and Thrips tabaci Lind: a review. In: A.J.M. Loomans, J.C. van Lenteren, M.G. Tommansini,
S. Maini, J. Riudavets (eds.), Biological Control of Thrips Pests. Wageningen pp. $43-87$

13. Wright RJ (2004) Minute pirate bugs. Biological Control News formerly Midwest Biological Control News. Vol. 1: 1. http://www.entomology. wisc.edu/mbcn/ mben.html

14. Isenhour DJ, Layton RC, Wiseman BR (1990) Potential of adult Orius insidious (Hemiptera: Anthocoridae) as a predator of the fall armyworm, Spodoptera frugiperda (Lepidoptera: Noctuidae). BioControl 35: 269-275.

15. Fox TB, Landis DA, Cardoso FF, DiFonzo CD (2004) Predators suppress Aphis glycines Matsumura population growth in soybean. Environmental Entomology 33: $608-618$

16. Rutledge CE, O'Neil RJ, Fox TB, Landis DA (2004) Soybean aphid predators and their use in integrated pest management. Ann. Entomol. Soc. Am. 9: 240 248

17. Baez I, Reitz SR, Funderburk JE (2004) Predation by Orius insidiosus (Heteroptera: Anthocoridae) on the life stages and species of Frankliniella flower thrips (Thysanoptera: Thripidae) in pepper flowers. Environmental Entomology 33: 662-670.

18. van den Meiracker RAF, Ramakers PMJ (1991) Biological 314 control of the western flower thrips Frankliniella occidentalis, in sweet pepper, with the anthocorid predator Orius insidiosus. Med. Fac. Landbouwn. Rijksuniv.Gent. $56: 241-249$

19. Copping LG (2004) A World Compendium: The Manual of Biocontrol Agents. 3rd Ed. Of the BioPesticide Manual. BCPC Pub. Hampshire, UK, 702pp.

20. Ahmad A, Wilde GE, Whitworth RJ, Zolnerowich G (2006) Effect of corn hybrids expressing the coleopteran-specific cry3Bb1 protein for corn rootworm contro on aboveground insect predators. J Econ Entomol 99: 1085-1095.

21. De la Poza M, Pons X, Farinos GP, Lopez C, Ortego F, et al. (2005) Impact of farm-scale Bt maize on abundance of predatory arthropods in Spain. Crop Prot. 24: 667-684.

22. Head G, Moar W, Eubanks M, Freeman B, Ruberson J, et al. (2005) A multiyear, large-scale comparison of arthropod populations on commercially managed $B$ and non-Bt cotton fields. Environmental Entomology 34: 1257-1266.

23. Dively GP (2005) Impact of transgenic VIP3A x Cry1Ab lepidopteran- resistant field corn on the non-target arthropod community. Environmental Entomology 34: 1267-1291.

24. SAS Institute (2003) SAS user's guide version 9.1, Cary, NC

25. Fernandes OP, Faria M, Martinelli S, Schmidt F, Carvalho VF, et al. (2007) Short-term assessment of Bt maize on non-target arthropods in Brazil. Sci. Agric. 64: 249-255.

26. Rose R, Dively GP (2007) Effects of insecticide-treated and Lepidopteranactive Bt transgenic sweet corn on the abundance and diversity of arthropods. Environ Entomol 36: 1254-1268.

27. Sabelis MW, van Rijn PCJ (1997) Predation by Insects and Mites. In "Thrips as Crop Pests" (T. Lewis, Ed.). CAB-International, London, pp. 259-354.

Submit your next manuscript and get advantages of OMICS Group submissions

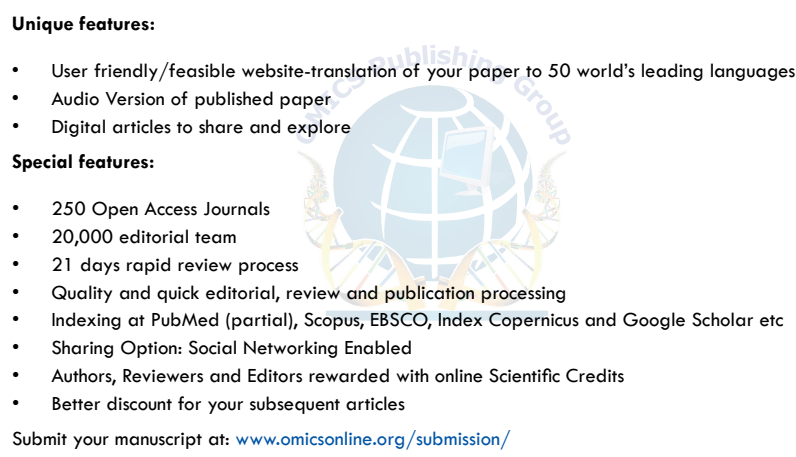
Non Target Effect of Cry1 Ab and Cry Ab x Cry3 Bb1 Bt Transgenic Maize on Orius insidiosus (Hemiptera: Anthocoridae) Abundance. Entomol Ornitho Herpetol 2: 107. doi:10.4172/2161-0983.1000107 